\title{
Wstęp
}

\section{Własny głos}

Anna Nasiłowska

TEKSTY DRUGIE 2019, NR 3, S. 7-11

DOI: $10.18318 /$ td.2019.3.1 | ORCID: 0000-0002-6171-5662

ata z ósemką i dziewiątką obfitują w rocznice: zakończenia I wojny światowej, stulecia odzyskania niepodległości, stulecia uzyskania praw wyborczych przez kobiety, trzydziestolecia transformacji ustrojowej... Okrągła data to nie najlepszy powód, aby podejmować jakiś temat, zwraca ona jednak uwagę na nie do końca przemyślane fragmenty doświadczenia historycznego. Kłopoty z pamięcią o I wojnie światowej w dużej mierze wynikają z tego, że polska pamięć zbiorowa jest unarodowiona, stanowi opowieść o różnych próbach odzyskania podmiotowości państwowej, a więc z pewnym trudem mieszczą się w niej fragmenty niezgodne z zasadniczym tematem, trudne do wpisania w zbiorowy podmiot wspólnego przeżywania, a tak w okresie I wojny było - inna jest historia zaboru rosyjskiego, inna wiąże się z obszarem koalicji państw centralnych. Literackie świadectwa tego okresu są dość bogate, ale jakby pozbawione znaczenia i siły wpisania się w zasadniczy nurt.

Pierwsze wybory, w których uczestniczyć mogły kobiety, to niewątpliwie jeden z kamieni milowych wieńczących długi proces emancypacji, a także powód do dumy. Jak pisał autor popularnej biografii Emmeline Pankhurst: „Anglia uznała prawa swoich kobiet o rok wcześniej niż Polska, o dwa lata wcześniej niż większość stanów Ameryki Północnej, o trzy lata - niż Szwecja,

\section{Anna}

Nasiłowska - prof. dr hab., pracownik IBL PAN, członkini Zespołu Literatura i Gender IBL PAN. Zastępca redaktora naczelnego „Tekstów Drugich", prezeska Stowarzyszenia Pisarzy Polskich. Ostatnio opublikowała biografię Marii Pawlikowskiej-Jasnorzewskiej (2010), wybór pism Stefanii Zahorskiej (2010), reportaż historyczny Wolny agent Umeda i druga Japonia (2013), tom poezji Ciemne przejścia (2018) oraz Dyskont słów (2016). Współredaktorka Encyklopedii gender (2014). Kontakt: anna. nas@wp.pl 
dwadzieścia osiem lat - niż Francja, dwadzieścia dziewięć lat niż Chiny, trzydzieści lat niż Egipt. A Szwajcarki uzyskały prawa wyborcze dopiero w roku 1971!"”. Mniejsza o drobną nieścisłość historyczną, w 1918 roku Polska dopiero zaczynała istnieć jako podmiot polityczny, a 6 lutego 1918 roku, gdy w Anglii odpowiednią ustawę podpisał Król Jerzy V - jeszcze jej nie było.

W Polsce dążenia do przyznania praw wyborczych kobietom nie pociągnęły za sobą aż takich ofiar, jakie ponieść musiały angielskie sufrażystki, które wybijały szyby, podkładały bomby i nie cofały się przed innymi aktami przemocy, a także podlegały surowym karom więzienia, podejmowały głodówki i ryzykowały - a niektóre wręcz poświęciły - życie dla sprawy. Łagodne przejście nie pozostawia jednakże takich śladów w pamięci, co gwałtowne wydarzenia i świadoma walka. A jednak... Czy nie do tej zasadniczej zmiany odnosi się fragment Granicy Zofii Nałkowskiej, gdy zgromadzone w mieszczańskim salonie kobiety, podczas imienin pani Cecylii Kolichowskiej mówią o „czasach, jakie nadeszły, o wojnie, o bolszewikach, o Żydach. I o służących".Ten ostatni temat rozrasta się:

Pani Cecylia powiedziała surowo, że jej zdaniem służąca to jest taki sam człowiek, jak każdy inny. Pamiętała tę prawdę z czasów pierwszego małżeństwa. Na to zgodziły się zasadniczo wszystkie panie

„Taki sam człowiek, naturalnie" - powtórzyły jedna po drugiej, ale coraz ciszej, jakby stopniowo ogarnięte zastanowieniem. Elżbieta wiedziała, że kłamią. Służąca to jest zupełnie inne stworzenie, wcale nie takie samo jak każdy inny człowiek. Wystarczy powiedzieć: „panna Marianna" - i już można się śmiać. ${ }^{2}$

Ten fragment, z początkowych partii książki, niejako antycypuje zasadniczy konflikt powieści i przedstawia dziecinną jeszcze świadomość Elżbiety, popartą obserwacją i doświadczeniem, a nie poglądami. Hanna Kirchner, autorka przedmowy i opracowania powieści, zwraca uwagę, że pierwszy mąż pani Kolichowskiej był socjalistą, jej deklaracja ma więc lewicowe podłoże ideowe. Potem Elżbieta wykształci w sobie wrażliwość społeczną, zauważy, że jej kanapa, na której siada podczas rozmów z Zenonem, umiejscowiona jest bezpośrednio nad pozbawioną światła komórką, w której w zatęchłym powietrzu dogorywa rodzina Gołąbskich. Tam także pojawi się Justyna, gdy straci posadę służącej. Założona, deklarowana werbalnie równość podmiotów w odmienionym

1 G. Bidwell Bunt długich spódnic, przeł. A. Bidwell, Wydawnictwo „Śląsk”, Katowice 1972, s. 221.

2 Z. Nałkowska Granica, wstęp i oprac. H. Kirchner, Biblioteka Narodowa, Ossolineum, Wrocław 2016, s. 29-30. Dalsze cytaty z tego wydania. 
po wielkiej wojnie świecie, którego pojęcia przeorała rewolucja i procesy emancypacji, zderza się z praktyką, z drastycznymi nierównościami ekonomicznymi i odmiennymi możliwościami, jakie wynikają z siatki powiązań społecznych i edukacji. Elżbieta to kulturalna panna z potencjałem awansu, jej matka należy bowiem do najwyższych sfer; Justyna - służąca, dziecko kucharki, może haftować bieliznę lub sprzedawać w sklepie, choć taka praca wymaga już protekcji. Sformalizowany związek z nią nie wchodzi w grę, mógłby wyłącznie degradować Zenona nie tyle ze względu na jej pochodzenie, co na różnice w edukacji. On - uzyskał doktorat z nauk politycznych w Paryżu, o jej edukacji nie wiemy nic, a wymowne świadectwo jej niezadowalającego poziomu przynosi fatalna w skutkach rozmowa między Elżbietą jako administratorką domu a Justyną, tymczasową mieszanką piwnicy Gołąbskich, podczas której dochodzi do konfrontacji uczuć, pozycji i dwóch sposobów ekspresji językowej.

Najpierw Elżbieta obserwuje Justynę, odwlekając chwilę rozmowy: „Myślała z pretensją do niego, że tak zła jest ta suknia ze sztucznego jedwabiu w kwiatki, i z przykrością, przez którą przelatywała rozkosz, że nie jest szczupła" (s. 188). Nie tylko ubranie, ale nawet ciało, szczupłe kształty są oznaką miejsca w społecznej hierarchii, i tak, z pewnymi korektami, pozostało do dziś, z nowymi elementami mody na bycie vege i fit. Potem Justyna, w odpowiedzi na pytanie, czy kocha Zenona, wydobywa z siebie wiejski lament: „O ja przeklęta, że ja nie miałam rozumu! Co mu było do mnie, po co mnie ruszał? Czy ja mu wchodziłam w drogę? Mnie chłopaki nie byli w głowie, mnie było dobrze". I kontynuuje: „Teraz ja mu jestem za prosta, teraz on się zrobił pan! A co ja jestem gorszego? Każdy wie, że ci państwo z Boleborzy to wcale nie państwo. Jego ojciec jest taki sam karbowy jak każdy drugi. Pana teraz będzie udawał!". Pojęcia społeczne Justyny, jej wyobrażenie hierarchii jest wiejskie, feudalne, z folwarku, a nie miejskie, związane z edukacją i sprawowanymi funkcjami. Ponieważ odpowiedź na pytanie o uczucia nie pada, Elżbieta pyta jeszcze raz i uzyskuje następną serię wiejskich wykrzykników: „Ja go kocham jak tego psa wściekłego! Czy mi to było potrzebne?" (s. 189-190). Kulturalna i delikatna panna popełnia błąd, uważając pretensje dziewczyny za świadectwo uczuciowego zerwania. W tej sferze społecznej uczucia wypowiada się odmiennie, wyrzekanie jest oznaką emocji i wciąż niewygasłego napięcia między kobietą a mężczyzną.

To jeden z niezbyt licznych momentów w tekście powieści, gdy przemawia sama Justyna, gdy kluczowa dla akcji bohaterka zabiera głos i po swojemu formułuje zdania. Poza tym widzimy ją siedzącą ze spuszczoną głową, poznajemy poprzez często sprzeczne relacje innych o niej. Jej gwałtowna mowa, jej wiejski sposób nazywania, ludowa frazeologia - nie mieszczą się w eleganckiej, wysokiej formule prozy modernistycznej Zofii Nałkowskiej. W końcowych partiach powieści dowiadujemy się, że Justyna, zanim zaatakowała, napisała do Zenona Ziembiewicza kilka listów, były one 
gwałtowne, niezborne i niewiele z nich rozumiał, ale nasunęły mu myśl o jej chorobie psychicznej. Treści żadnego z listów nie poznajemy, nawet w urywkach. Rewelacyjność opowiadań Marii Dąbrowskiej z tomu Ludzie stamtąd (z 1926 roku) polega na prowadzeniu ludowego narratora wraz z jego językiem; Granica pochodzi z 1935 roku, ale Zofia Nałkowska nie posłużyła się wprowadzeniem na szerszą skalę mowy postaci, gdyż rozbiłoby to elegancki tok opowieści. W tej chwili powieściopisarz nie ma w ogóle do dyspozycji jędrnej polszczyzny wiejskiej, która zanikła wraz z jej konkretnością i całym bogactwem frazeologii odnoszącej się do wściekłych psów, głupich gęsi i krów, może jedynie świnie przetrwały w potocznych powiedzonkach. Współczesny autor nie zmarnowałby jednak okazji, jeśli mógłby zastosować pokrętny tekst postaci w formie przytoczenia. Sprzeczność z klasyczną logiką czy wręcz zuchwały absurd, na przykład w prozie Masłowskiej, charakteryzują malowniczy świat językowy bohatera. Stoi za tym nowy ład społeczny i powojenny masowy awans: nie ma już ludu, są ludzie spoza warstw kulturalnych, przemawiający bluzgiem, chełpliwi i pozbawieni autorefleksji.

Wysoka modernistyczna dykcja Nałkowskiej dobrze opisuje paradoksy świeżej demokracji w dwudziestoleciu. Moja kolejna (chyba czwarta w życiu?) uważna lektura tej powieści nareszcie pozwoliła, by zdystansować się od wymuszonej szkolnej interpretacji z poprzedniej epoki, która długo przesłaniała sam tekst, podsuwając zbyt łatwe stereotypy: że oto zła władza gnębi lud pracujący miast i wsi, powieść przynosi więc obraz win moralnych klas posiadających, wykorzystujących lud ekonomicznie, a także seksualnie. U Nałkowskiej nic nie jest łatwe i nie wiadomo, co zrobić, sprzeczności trwają, wzajemnie blokując się: Justyna jest niedojrzała, Elżbieta - bezwolna, a żaden z bohaterów nie zyskuje tyle współczucia, aby jego los wydawał się poruszający. Poruszający jest mechanizm deziluzji, bezwyjściowość sytuacji i wewnętrzna logika zdarzeń.

Numer, który oddajemy do rąk Czytelników, łączy ze sobą refleksję wokół praw wyborczych kobiet i problemów nowych gatunków literackich. Prawo bycia zauważonym, wypowiedzianym, prawo do własnej opowieści mają wiele wspólnego z prawami politycznymi. 


\section{Abstract}

\section{Anna Nasiłowska}

THE INSTITUTE OF LITERARY RESEARCH OF THE POLISH ACADEMY OF SCIENCES (WARSAW)

Their Own Voice

Nasiłowska explores the representation of themes such as World War I and women's suffrage in Polish fiction of the first half of the twentieth century. The act of remembering the Great War, she argues, is made difficult because the experience cannot be inscribed into a series of events in Poland's national history; the early establishment of universal suffrage, meanwhile, explains why the battle for women's voting rights has failed to become a major theme. In Zofia Nałkowska's novel Granica [Boundary], a classic of the interwar period, the theme of equality in a democratic society is present, but uneducated characters rarely get to articulate their position in their own words.

\section{Keywords}

Zofia Nałkowska, Boundary, women's rights, emancipation, subjectivity, modernist novel 